Proceedings of the International Conference on Teaching, Education and Learning Conference, Vol. 1, 2021, pp. 74-86

Copyright (C) 2021 iConferences

ISSN 2820-2155

DOI: https://doi.org/10.32789/tel.2021.1006

\title{
The Dominance of E-Learning Methods over Studies: Problems and Solutions
}

\author{
Suraa A. Abbas
}

Santiago de Compostela University, Galicia, Spain, suraaamer.abbas@rai.usc.es 


\title{
THE DOMINANCE OF E-LEARNING METHODS OVER STUDIES: PROBLEMS AND SOLUTIONS
}

\begin{abstract}
This paper sheds light on e-learning, whose importance has swiftly grown over the past year by learners after the closure of schools and universities in more than 100 countries worldwide due to the rampant Coronavirus disease (COVID-19), and the problems and solutions that must be followed to facilitate the educational process. This study is mainly quantitative. It will use quantitative research methods to collect data by distributing questions to the research community consisting of 10 teachers and 30 undergraduate students in the medical, technical faculty at Al-Kitab University. The data were analyzed by content analysis technique and divided into themes, subthemes, and codes. The paper found that both students and teachers used technology to ensure the continuity of the educational process. In addition, both teachers and learners have different positive and negative opinions about the distance education platforms and the conditions facing them from the weakness of the Internet and the liability of electronic skills for both parties. Ideas were put forward on developing equipment and methods used for distance education activities using artificial intelligence to simulate the natural educational environment. This study recommends educational institutions restructure the curriculum and make it compatible with the electronic environment, just like the real academic environment.
\end{abstract}

Keywords: E-learning, Coronavirus, education, technology

\section{Introduction}

Due to the Coronavirus (covid-19) outbreak since last year and the increase in patient cases, precautionary measures have been taken to reduce the rate of infections; among these measures are social distancing (social isolation), quarantine practices, travel restrictions, closure of all schools, universities, government, and private institutions except health facilities.

In today's world, Universities are living in general transformations imposed by health conditions that have led to the transformation of all educational institutions dealing with face education that allows physical closeness, which constitutes an opportunity for infection to spread to e-learning or distance education. UNESCO (2020) reported that "there have been 1,576,021,818 affected learners out of 91.3\% total enrolled learners in 188 countries in all levels of learning". The teachers faced challenges that forced them to use technology to educate their students (Fox, 2007).

Distance learning or electronic learning has long been discussed and argued about the need to integrate it into the educational process before the Coronavirus pandemic. However, it became an alternative and an urgent necessity to continue education in conditions that impose physical distancing. Koumi (2006) believes that e-learning came as a result of technological developments, especially after the educational process was directly affected by the automation of industry and the development of "artificial intelligence technology" as well as the information technology revolution that entered the classroom and became an integral part of it.

People have understood the importance of e-learning after the coronavirus pandemic. It has become a method used to provide interaction between students and teachers due to limitations in the education and training process (Eygü \& Karaman, 2013; Moore, Deane \& Galyen, 2013). According to Allen et 
al. (2010), "Distance education is considered a promising innovation with its flexible learning environments."

Education was the most affected by this virus. According to (Sonnmez 1991), it can be defined as a process of change in values and behavior in the desired direction through environmental adjustment. Miser pointed out that education, knowledge development, and the ability to use the information and generate new things can only be achieved through education and emphasized the need for people to continue education throughout their lives (Miser, 2002). Icten (2006) defines distance education as an alternative method to traditionally applied education methods. Students communicate and interact with teachers in an improved manner using technology to create educational environments. (Koumi, 2006) added that e-learning is education provided on the Internet through modern electronic technologies to reach everything related to educational materials outside the traditional academic classroom boundaries. Moreover, to avoid wasting time getting an education (Karakeçeli, 2019) indicated that it is necessary to keep pace with technological development to prevent disruptions in education. In light of these views, Basilaia and Kvavadze (2020) believe that e-learning is an organized process that aims to achieve educational outcomes using technological means that provide sound, image, films, and interaction between the learner, content, and educational activities at the appropriate time and time.

In digital platforms, the instructions are divided into synchronous (online) or asynchronous (offline). If the education is asynchronous, students and teachers are not in the same timeframe, but students can access the lecture any time in a virtual environment. In simultaneous education, students and teachers are on the same electronic platform simultaneously, and lessons are given and questions answered directly over the Internet. (Arslan, 2019) indicated that studies in simultaneous education could be viewed at any time just as asynchronous education.

Medical Technology faculty at Al-Kitab University is one of the universities that suddenly forced itself to switch to e-learning and employ the means of communication that were not used before. Some problems also appeared in the application of E-learning, including poor employment of some elearning software because Al-Kitab University did not follow E-learning or distance learning beforehand, in addition to the weakness of the e-learning infrastructure that requires the adoption of specific software and the provision of Internet networks and smartphones for every student. Therefore, an urgent need has emerged to know and evaluate the effectiveness of E-learning, the extent to which it achieves education goals, its ability to meet students' needs, and create an interactive environment that replaces face-to-face learning.

\section{The purpose of the study}

In this study, the purpose is to examine E-learning's effectiveness on education in medical technology faculty at Al-Kitab University. Furthermore, to investigate the challenges that hinder the students and teachers Thus, it seeks to answer the following questions: 
1. What is the effectiveness of e-learning on education in medical technology faculty at Al-Kitab University?

2. What challenges hinder the students and teachers in medical technology faculty at Al-Kitab University during e-learning?

\section{Background}

Education in Coronavirus pandemic

A short time ago, it was believed that the Internet was nothing but a place for chatting, reading newspapers, shopping, and seeing forums. The Internet began to be used in educational institutions, and knowledge was exchanged through communication, and there became websites for schools and universities on the Internet. The perception of the Internet, smartphones, and computers has changed; it has become an essential educational tool as the number of schools and universities connected to the Internet increases daily. Google search results revealed that there are more than (400) online universities and colleges, more than $(35,000)$ teachers and $(250,000)$ students are using e-learning before the Corona pandemic, and that there are university portals and more than (1700) university courses on the Internet in The United States only (Koumi, 2006).

Before March 2020, no faculty member had any idea that e-learning would be the only portal to reach students and interact with them to achieve educational goals. More than 1.3 billion learners have been out of school due to school closures in response to COVID-19 (Wikipedia, 2020). According to Erika and Nicholas (2020), school closures can be either reactive or proactive. Erika and Nicholas also stated that reactive closing schools are a reaction that occurs when a coronavirus case is discovered among students, staff, and parents. Meanwhile, proactive school closure occurs before the disease reaches the school gates. Madeline (2020) argues that school closures due to the coronavirus may pose new problems, such as transitioning to online learning from home and meeting the needs of those who depend on school for food and housing security. As a result of the coronavirus crisis, courses for teachers in the field of e-learning and its various means have been intensively established to maintain the continuity of education and learning, to achieve the requirements for completing the 2020 academic year, and to achieve physical distancing among students to preserve their safety from infection with the coronavirus.

Covid-19 is a new disease that humans have not previously discovered. It is a viral disease that affects the respiratory system of people of all ages. The people most affected and vulnerable to it are the elderly and those with chronic disease conditions, and it may spread among people quickly. According to UNESCO (2020), there are harmful effects of school closures due to the Coronavirus, such as interrupted education and unequal access to electronic education platforms due to poor internet connection, in addition to increasing psychological pressure on schools by parents of students who are demanding the opening of schools due to the necessity of communication, social learning, development, and creativity that the student is deprived of due to social isolation.

Adherence to the instructions of the Ministry of Health in Iraq has led to the prevention of all forms of physical rapprochement between citizens and has stopped face-to-face education, and has adopted e-learning in the continuity of the 2020- 2021 academic year, in markets, mosques, and clubs, and AlKitabUniversity one of the educational institutions that followed these instructions. Erika and 
Nicholas (2020) suggested giving parents of students the flexibility to choose the best fit for their families and said closing schools is not the only option to reduce coronavirus infections. The president of the New South Wales Teachers disputed the opinion of Erika and Nicholas and expressed his belief that "the design of their schools and the size of the classrooms makes it impossible" to implement social distancing in schools" (Michael, 2020). Thus, to slow the spread of the virus, students and teachers quickly adapted to e-learning platforms to ensure the continuation of education.

\section{Review of literature}

\section{Challenges using e-learning during Covid-19}

The Internet plays an essential role in the teaching process, as it is considered an extensive library in which all sources of information are available. It also provides access to the latest scientific and educational research. By employing the Internet, a faculty member can consider the individual differences between students, identify their weaknesses, and put forward additional activities consistent with their needs, thus improving the quality of learning and education. The Internet also helps reduce the effort and time of the faculty member, especially in routine work, which enables him to invest his time and effort in planning situations and learning experiences that contribute to the development of students' personalities in intellectual and social aspects. Distance education has many benefits, such as ensuring education sustainability (Akinbadewa \& Sofowora, 2020; Seage \& Türegün, 2020), providing lifelong learning (Alharthi, 2020). However, there are some restrictions and challenges that students, teachers, and parents have faced in the last year due to e-learning, especially in third-world countries where the use of technology in education and digital skills is insufficient, besides network issues, inadequate power supply. There is also a problem of time to learn new technologies required to learn from home. (Gökdaş \& Kayri, 2005) indicated many obstacles to e-learning or distance learning, such as economic reasons, lack of awareness and experience in using e-learning, technical staff problem, and poor utilization of information technologies. Spodark (2003) believes that there are obstacles that appear when thinking about using the e-learning process, as the design of the course takes longer time and needs more effort, deep thinking, and more communication, the need for frequent feedback, also an increase in the explanation and cost, including connection and printing cost. However, he rectifies by saying that a good teacher in the traditional teaching system is likely to be a good teacher in the new system in which the Internet is employed; he also confirms that the transformation is not easy and requires effort and perseverance, patience, and enthusiasm. Doodley, K.\&Tim M. (2007) emphasize that researching teachers' attitudes towards using technology and its importance in education is more important than knowing the problems of the network in education; he talks about one of the most important reasons for some teachers' reluctance to use technology is due to the lack of awareness of the importance of this technology first, and the inability to use it secondly. He mentioned that in most American colleges, there are no more than 2 out of every ten teachers, who can be considered severe users of the computer and the Internet in teaching, even though 7 out of 10 own computers in their homes and use them in preparing for lessons and communicating with others. He called for the necessity of setting up training programs for faculty members, especially using computers in general and using the Internet. 
Human nature does not tend to change the behavior accustomed, which applies to teaching staff members. Fallatah (1995) mentioned three forms of this reluctance:

1. Adhere to the old or prevailing educational methods

2. Unwillingness to adapt to modern methods and technologies.

3. Feeling of disinterest and indifference towards new changes.

Some studies confirm that teachers themselves resist change. Ayers (2006) has concluded that the causes of resistance by the teachers are the lack of time, costs, and effort required to apply modern technologies, including the Internet, in the educational process and the complete incompatibility between the academic community and technicians.

\section{Methodology}

\section{Study Approach}

This study relied on its procedures on the descriptive and analytical approach, which relies on collecting data from the study sample of students and teachers, studying their responses, and analyzing it using the questionnaire prepared for this study.

\section{Study sample}

This study applied to 10 teachers and 30 students from the Faculty of Medical Analytics. The study sample was selected from the second stage at Al-Kitab University and the stage professors for 20202021 from various disciplines contacted through social media.

\section{Data collection tool}

To achieve the objectives of this study, a questionnaire was built divided into two parts, the first for students and the second for teachers who practiced e-learning during the crisis of the spread of the Coronavirus; each section contains ten questions. The questionnaire was developed by reviewing studies that dealt with e-learning (Yulia, 2020) and (Basilaia, Kvavadze, 2020). The questionnaire was finalized from a five-point scale (strongly agree, agree, neutral, disagree, Strongly Disagree).

\section{Research Process and Data Analysis}

The data was collected using the study tool, a questionnaire sent to the participants through the electronic environment to maintain social distancing due to the continuing COVID-19 pandemic. After coding the answers, the data was entered into an Excel file, organized, and entered into the statistical program (SPSS) to analyze the study data. Descriptive statistics were used to calculate the standard deviations. 


\section{Results and Analysis}

Table 1: Distribution of respondents by Gender

\begin{tabular}{llcc}
\hline & & Count & Table N \% \\
\hline University & Al-kitab university & 30 & $100.0 \%$ \\
\hline Educational level & Bachelor & 30 & $100.0 \%$ \\
\hline \multirow{2}{*}{ Gender } & male & 13 & $41.9 \%$ \\
\cline { 2 - 4 } & female & 17 & $58.1 \%$ \\
\hline
\end{tabular}

Table 1 above depicts the distribution of respondents by gender and educational qualifications. It can be inferred from the table that $41.9 \%$ of the respondents were males while $58.1 \%$ were females. This implies that the majority of the respondents were females. Both genders were undergraduates by $100.0 \%$.

Table 2: Views of students on E-Learning

\begin{tabular}{|c|c|c|c|}
\hline \multicolumn{2}{|c|}{ Point scale } & \multirow{2}{*}{$\begin{array}{c}\text { Count } \\
2 \\
\end{array}$} & \multirow{2}{*}{$\frac{\text { Table Total N \% }}{6.5 \%}$} \\
\hline & Strongly agree & & \\
\hline \multirow{5}{*}{$\begin{array}{l}\text { The internet speed is adequate, and I } \\
\text { can access lectures without } \\
\text { interruption }\end{array}$} & Strongly Disagree & 8 & $25.8 \%$ \\
\hline & Disagree & 11 & $35.5 \%$ \\
\hline & neutral & 3 & $9.7 \%$ \\
\hline & agree & 8 & $25.8 \%$ \\
\hline & Strongly agree & 1 & $3.2 \%$ \\
\hline \multirow{5}{*}{$\begin{array}{l}\text { Sufficient courses have been provided } \\
\text { to use the site for the scientific } \\
\text { material }\end{array}$} & Strongly Disagree & 6 & $19.4 \%$ \\
\hline & Disagree & 8 & $25.8 \%$ \\
\hline & neutral & 5 & $16.1 \%$ \\
\hline & agree & 9 & $29.0 \%$ \\
\hline & Strongly agree & 3 & $9.7 \%$ \\
\hline \multirow{5}{*}{$\begin{array}{l}\text { The content displayed on the Internet } \\
\text { is sufficient and comprehensive for all } \\
\text { the material }\end{array}$} & Strongly Disagree & 1 & $3.0 \%$ \\
\hline & Disagree & 10 & $32.3 \%$ \\
\hline & neutral & 8 & $25.8 \%$ \\
\hline & agree & 10 & $32.3 \%$ \\
\hline & Strongly agree & 1 & $3.2 \%$ \\
\hline \multirow{5}{*}{$\begin{array}{l}\text { The distance education method helped } \\
\text { me to understand the scientific } \\
\text { material in a smooth and precise } \\
\text { manner }\end{array}$} & Strongly Disagree & 7 & $22.6 \%$ \\
\hline & Disagree & 8 & $25.8 \%$ \\
\hline & neutral & 8 & $25.8 \%$ \\
\hline & agree & 5 & $16.1 \%$ \\
\hline & Strongly agree & 3 & $9.7 \%$ \\
\hline \multirow{4}{*}{$\begin{array}{l}\text { Presenting the scientific material } \\
\text { electronically provided me with new } \\
\text { skills }\end{array}$} & Strongly Disagree & 4 & $12.9 \%$ \\
\hline & Disagree & 10 & $32.3 \%$ \\
\hline & neutral & 8 & $25.8 \%$ \\
\hline & agree & 6 & $19.4 \%$ \\
\hline
\end{tabular}


Table (2) the data in the above table regarding students' opinions of e-learning reveals that their views differ. The percentage regarding the question about the speed of the Internet to complete distance education came in first place with a rate of $35.5 \%$ of the sample do not agree. In contrast, "The content displayed on the Internet is sufficient and comprehensive for all the material" came last, with a weak $3.0 \%$ percentage which strongly disagrees. As for the rest of the questions, they varied between agree, strongly agree, and neutral in their opinions

Table 3: Ability to Receive Scientific Lessons from Distance Education

\begin{tabular}{|c|c|c|c|}
\hline \multicolumn{2}{|c|}{ Point scale } & \multirow{2}{*}{$\begin{array}{c}\text { Count } \\
2 \\
\end{array}$} & \multirow{2}{*}{$\frac{\text { Table Total N \% }}{6.5 \%}$} \\
\hline & Strongly agree & & \\
\hline \multirow{5}{*}{$\begin{array}{l}\text { The information we get from the } \\
\text { online lessons is equal to the } \\
\text { information we get in the real lessons }\end{array}$} & Strongly Disagree & 12 & $38.7 \%$ \\
\hline & Disagree & 8 & $25.8 \%$ \\
\hline & Neutral & 3 & $9.7 \%$ \\
\hline & Agree & 7 & $22.6 \%$ \\
\hline & Strongly agree & 14 & $45.2 \%$ \\
\hline \multirow{5}{*}{$\begin{array}{l}\text { I can ask any questions and inquiries } \\
\text { during distance learning, and I can } \\
\text { answer them easily }\end{array}$} & Strongly Disagree & 1 & $3.2 \%$ \\
\hline & Disagree & 8 & $25.8 \%$ \\
\hline & Neutral & 8 & $25.8 \%$ \\
\hline & Agree & 11 & $35.5 \%$ \\
\hline & Strongly agree & 1 & $3.1 \%$ \\
\hline \multirow{5}{*}{$\begin{array}{l}\text { Distance tests are done efficiently and } \\
\text { without hindrance }\end{array}$} & Strongly Disagree & 7 & $22.6 \%$ \\
\hline & Disagree & 6 & $19.4 \%$ \\
\hline & Neutral & 5 & $16.1 \%$ \\
\hline & Agree & 9 & $29.0 \%$ \\
\hline & Strongly agree & 4 & $12.9 \%$ \\
\hline \multirow{5}{*}{$\begin{array}{l}\text { The practical material is explained } \\
\text { thoroughly as it is described in the } \\
\text { laboratory }\end{array}$} & Strongly Disagree & 6 & $19.4 \%$ \\
\hline & Disagree & 8 & $25.8 \%$ \\
\hline & Neutral & 7 & $22.6 \%$ \\
\hline & Agree & 9 & $29.0 \%$ \\
\hline & Strongly agree & 1 & $3.2 \%$ \\
\hline \multirow{5}{*}{$\begin{array}{l}\text { The evaluation methods used are } \\
\text { appropriate and varied }\end{array}$} & Strongly Disagree & 4 & $12.9 \%$ \\
\hline & Disagree & 9 & $29.0 \%$ \\
\hline & Neutral & 7 & $22.6 \%$ \\
\hline & Agree & 8 & $25.8 \%$ \\
\hline & Strongly agree & 3 & $9.7 \%$ \\
\hline
\end{tabular}

Table (3) shows the paragraphs "presentation of scientific material from distance education" ranged from a weak to a medium percentage. The paragraph "I can ask any questions and inquiries during distance learning, and I can answer them easily" came in first place with a rate of $45.2 \%$, while "Distance tests are done easily and without hindrance" came last, with a weak 3.1\% percentage. 
Table 4: Teachers' Opinion on Distance Education

\begin{tabular}{|c|c|c|c|}
\hline & & Count & Table N \% \\
\hline \multirow{5}{*}{$\begin{array}{l}\text { I think the e-learning platform is } \\
\text { helpful in teaching }\end{array}$} & strongly disagree & 3 & $21.4 \%$ \\
\hline & Disagree & 2 & $14.3 \%$ \\
\hline & Neutral & 3 & $21.4 \%$ \\
\hline & Agree & 6 & $42.9 \%$ \\
\hline & strongly agree & 0 & $0.0 \%$ \\
\hline \multirow{5}{*}{$\begin{array}{l}\text { The use of e-learning platforms } \\
\text { requires new skills on the part of the } \\
\text { teaching staff }\end{array}$} & strongly disagree & 2 & $7.2 \%$ \\
\hline & Disagree & 2 & $7.2 \%$ \\
\hline & neutral & 0 & $0.0 \%$ \\
\hline & Agree & 8 & $57.1 \%$ \\
\hline & strongly agree & 4 & $28.6 \%$ \\
\hline \multirow{5}{*}{$\begin{array}{l}\text { The college and university provide } \\
\text { the necessary courses to improve } \\
\text { skills in using technology in } \\
\text { education }\end{array}$} & strongly disagree & 2 & $14.3 \%$ \\
\hline & Disagree & 2 & $7.2 \%$ \\
\hline & neutral & 3 & $21.4 \%$ \\
\hline & Agree & 8 & $57.1 \%$ \\
\hline & strongly agree & 0 & $0.0 \%$ \\
\hline \multirow{5}{*}{$\begin{array}{l}\text { E-learning platforms can be used in } \\
\text { conjunction with traditional } \\
\text { education without being interrupted }\end{array}$} & strongly disagree & 3 & $21.4 \%$ \\
\hline & Disagree & 2 & $14.3 \%$ \\
\hline & neutral & 2 & $14.3 \%$ \\
\hline & Agree & 5 & $35.7 \%$ \\
\hline & strongly agree & 2 & $14.3 \%$ \\
\hline \multirow{4}{*}{$\begin{array}{l}\text { The e-learning system is appropriate } \\
\text { for the type of material, both } \\
\text { theoretical and practical }\end{array}$} & strongly disagree & 3 & $21.4 \%$ \\
\hline & Disagree & 7 & $50.0 \%$ \\
\hline & neutral & 1 & $7.1 \%$ \\
\hline & Agree & 3 & $21.4 \%$ \\
\hline
\end{tabular}

Table (4) shows the paragraphs "Teachers' Opinion on Distance Education" ranged from a weak to a medium percentage. Both paragraphs, first "The use of e-learning platforms require new skills on the part of the teaching staff" and "The college and university provide the necessary courses to improve skills in using technology in education," come in first place with a percentage of $57.1 \%$ agree. In contrast, "The e-learning system is appropriate for the type of material, both theoretical and practical," came last, with a weak 7.1\% percentage which the teachers' opinion was neutral about.

Table 5: Teachers' Opinion on Assessing Students in the Electronic Environment

\begin{tabular}{llcc}
\hline & & Count & Table N \% \\
\hline E-learning platforms help me follow & strongly disagree & 3 & $21.4 \%$ \\
\cline { 2 - 4 } $\begin{array}{l}\text { students and communicate with them } \\
\text { in an easier way }\end{array}$ & Disagree & 5 & $35.7 \%$ \\
\cline { 2 - 4 } & Neutral & 2 & $21.4 \%$ \\
\cline { 2 - 4 } & Agree & 1 & $14.3 \%$ \\
\cline { 2 - 4 } & strongly agree & 2 & $7.1 \%$ \\
\hline Education platforms give me a & strongly disagree & $14.3 \%$ \\
\hline
\end{tabular}




\begin{tabular}{|c|c|c|c|}
\hline \multirow{4}{*}{$\begin{array}{l}\text { complete picture of the extent to which } \\
\text { students interact with educational } \\
\text { content }\end{array}$} & Disagree & 5 & $35.7 \%$ \\
\hline & neutral & 5 & $35.7 \%$ \\
\hline & Agree & 2 & $14.3 \%$ \\
\hline & strongly agree & 0 & $0.0 \%$ \\
\hline \multirow{5}{*}{$\begin{array}{l}\text { Reliance on e-learning does not lead to } \\
\text { students neglecting the scientific } \\
\text { subject }\end{array}$} & strongly disagree & 5 & $35.7 \%$ \\
\hline & Disagree & 2 & $14.3 \%$ \\
\hline & neutral & 4 & $28.6 \%$ \\
\hline & Agree & 2 & $14.3 \%$ \\
\hline & strongly agree & 1 & $7.1 \%$ \\
\hline \multirow{5}{*}{$\begin{array}{l}\text { The e-learning system allows the } \\
\text { student to access the educational } \\
\text { material at any time }\end{array}$} & strongly disagree & 1 & $7.1 \%$ \\
\hline & Disagree & 1 & $7.1 \%$ \\
\hline & neutral & 1 & $7.1 \%$ \\
\hline & Agree & 9 & $64.3 \%$ \\
\hline & strongly agree & 2 & $14.3 \%$ \\
\hline \multirow{5}{*}{$\begin{array}{l}\text { I believe that distance exams are an } \\
\text { appropriate way to assess student } \\
\text { achievement }\end{array}$} & strongly disagree & 3 & $21.4 \%$ \\
\hline & Disagree & 3 & $21.4 \%$ \\
\hline & neutral & 5 & $35.7 \%$ \\
\hline & Agree & 2 & $14.3 \%$ \\
\hline & strongly agree & 1 & $7.1 \%$ \\
\hline
\end{tabular}

Table (5) shows the paragraphs "Teachers' Opinion on Assessing Students in the Electronic Environment" ranged from a weak to a medium percentage. The paragraph "E-learning system allows the student to access the educational material at any time" comes first with a percentage of $64.3 \%$ agree. The same paragraph contains a weak rate of $7.1 \%$ between strongly disagree, disagree, and neutral. Followed by two sections, "e-learning platforms help me follow students and communicate with them more easily" and "I believe that distance exams are an appropriate way to assess student achievement," which contain the same weak percentage $7.1 \%$ strongly agree.

\section{Discussion}

The results, which were discussed in light of the sequence of study questions, are attributed to the fact that Al-Kitab University/Pathological Analysis Department is one of the universities that adopt faceto-face learning. Its plans did not adopt e-learning, so it suddenly turned to e-learning, and this reduces its experience in this field and makes this type of education a newcomer, needs the practice to improve its level. This result is also attributed to the fact that e-learning requires an infrastructure of computers, phones, tested and approved software in education, and the purchase of programs for the university to ensure the participation of the largest number of students in e-learning. Moreover, because e-learning was imposed on the university suddenly due to the Corona pandemic, the teaching was communicated with students within the available resources, which are weak capabilities. In addition to the fact that the university does not approve prior and reliable software to be employed in e-learning, which made some teachers communicate with students through social media, which are non-specialized programs for distance education. Some students and teachers do not trust the results of electronic exams; they do not take e-learning seriously.

There are also medium and weak obstacles that hinder e-learning, such as the absence of pre-approved educational software at the university, which made students advance in theoretical aspects. At the same time, they found difficulty in distance learning in practical elements. Besides, the speed of the Internet is not appropriate in some regions, which created a disparity in the reception and exchange of information and the occurrence of electricity in Iraq during the Corona crisis. This result is attributed to the fact that e-learning is an educational novelty imposed by the Corona pandemic, and every 
newcomer faces difficulty in the beginning. Experience comes later to remove many obstacles and adopt e-learning to suit the conditions of the learning environment in Iraq.

The results of these questions are similar to the study results (Draissi Yong 2020), which revealed that the response to the outbreak of the disease (COVID-19) and the implementation of distance education were facing some difficulties and challenges for both the teacher and the student. And the study (Yulia, 2020) revealed that the Corona pandemic had affected the reshaping of education in Indonesia, where the traditional method of teaching has retreated to spread instead of learning through the Internet because it supports learning from home and thus reduces people mixing and reduces the spread of the virus.

\section{Conclusion}

The Coronavirus crisis has affected the achievement of educational goals and, consequently, the university students. However, the education community has proven its ability to adapt in terms of updating educational means to suit distance education by setting up courses for students and teachers and training them on the use of distance education programs. But the negative effects of moving away from face-to-face education have not gone away. Nevertheless, each negative ring arising from the impact of socio-economic conditions gives a glimpse of the corresponding positive lock that can carry us to the future of education in which a complete change in the provision of education services, unleashing the potential of individuals, and collective self-realization, in all areas of life, by investing in education. The study emphasizes the need to adopt technology in education alongside real education, even after the Covid-19 crisis. In addition to the mobilization of untapped resources, the possible challenges instructors and learners face in an e-learning environment must be considered in order to ensure learner success. And the roles of teachers and students must include a transition away from traditional relationships between them, roles, and responsibilities to virtual space roles. Moreover, it is the instructor's primary role within the learning environment, which will help overcome challenges, support, and sustain student success. Finally, we can rely on restoring matters to normal and find all stakeholders in the education sector to achieve this future.

\section{Future Work}

The study is already done to examine the effectiveness of E-learning on education during COVID-19 lockdowns. The future study could be about the possibility of making E-learning side by side with face-to-face education.

\section{Acknowledgments}

All involved in this work.

\section{References}

Alharthi, M. 2020. Students' attitudes toward the use of technology in online courses. International Journal of Technology in Education (IJTE), 3(1), 14-23.

Allen, B., Crosky, A., Yench, E., Lutze-Mann, L., Blennerhassett, P., Lebard, R., Thordarson, P., \& Wilk, K. 2010. A model for transformation: A trans-disciplinary approach to disseminating good practice in blended 
learning in science faculty. In C. H. Steel, M. J. Keppell, P. Gerbic \& S. Housego (Eds.), Curriculum, technology \& transformation for unknown future. Sydney, Australia: The University of Queensland. Retrieved from http://ascilite.org.au/conferences /sydney10/procs/Allenfull.pdf

Akinbadewa, B. O., \& Sofowora, O. A. 2020. The effectiveness of multimedia instructional learning packages in enhancing secondary school students' attitudes toward Biology. International Journal on Studies in Education (IJonSE), 2(2), 119-133.

Arslan, V. 2019. Web-based distance learning experience and productivity analysis: the case of Istanbul University. Master Thesis. Istanbul University, Institute of Science, Istanbul.

Ayers, Edward L. "The academic culture and the IT culture: Their effect on teaching and scholarship," EDUCAUSE Review, volume 39, number 6 (November/December 2004), pp. 48-62. Available at: http://www.educause.edu/apps/er/erm04/erm0462.asp?bhcp=1, (visited on 12/12/2006).

Basilaia, G., \&Kvavadze, D. 2020. Transition to Online Education in Schools during a SARS-CoV-2 Coronavirus (COVID-19) Pandemic in Georgia. Pedagogical Research, 5(4), em0060. https://doi.org/10.29333/pr/7937 Retrieved, 27/5/2020.

Doodley, K. and Tim M. "College of Agriculture Faculty Perceptions of Electronic Technologies in Teaching". Journal of Agricultural Education. V. 42, Issue 2, pp 1-10 Available at: http://www.aged.tamu.edu/People/Faculty/dooley/pubs/42-02-01.pdf (visited on 2/1/2007)

Draissi, Z. Yong, Q, Z. 2020. COVID-19 Outbreak Response Plan: Implementing Distance Education in Moroccan Universities. School of Education, Shaanxi Normal University. https://papers.ssrn.com/sol3/papers.cfm?abstract_id=3586783

Eygü H., \& Karaman S. 2013. A study on the satisfaction perceptions of the distance education students. Kirıkkale University Journal of Social Sciences 3(1), 36-59.

Fallatah, Mustafa bin Muhammad Issa. Introduction to New Technologies in Communication and Education. 3rd Edition, Riyadh: King Saud University, Deanship of Library Affairs, (1995).

Fox, R. 2007. SARS epidemic: Teachers' experiences using it. Retrieved from https://www.google.com/url?sa=t\&source=web\&rct=j\&url=https://www.ascilite.org/conferences/perth04/procs/ pdf/fox.pdf\&ved=2ahUKEwi83IjD2N3oAhWmGEKHRgcCCUQFjABegQIAhAB\&usg=AOvVaw1pZFXsa8v wVtg_19X7YwtN

Gökdaş, İ. \& Kayri, M. 2005. E-öğrenme ve Türkiye açısından sorunlar, çözüm önerileri [E-Learning-The problems and solution recommends terms of Turkey situation]. Yüzüncü Y1l Üniversitesi Eğitim Fakültesi Dergisi [Van Yuzuncu Yil University Journal of Education], 2(2), 1-20.

İçten, T. 2006. Development of web-based online exam system application for distance learning students. Master's Thesis. Gazi University, Graduate School of Natural and Applied Sciences, Ankara.

Karakeçili, V. 2019. Comparison of attitudes of Y and Z generations towards online education technologies. Master's Thesis. Bahçeşehir University, Institute of Educational Sciences, Istanbul.

Koumi, J 2006. Designing Educational Video and Multimedia for Open and Distance Learning. Routledge, England.

Miser, R. 2002. Adult education in a globalized world. Ankara University. Journal of Faculty of Educational Sciences, 35(1), 55-60.

Sönmez, V. 1991. Philosophy of Education. Adam Publishing: Ankara.

Seage, S.J., \& Türegün, M. 2020. The effects of blended learning on STEM achievement of elementary school students. International Journal of Research in Education and Science (IJRES), 6(1), 133-140.

Spodark, Edwina. "Five Obstacles to Technology Integration at a Small Liberal Arts University".Technological Horizons In Education, Vol. 30, 2003 . Available at: http://www.thejournal.com/articles/16293 (visited on 16/12/2006) 
UNESCO 2020. Global Monitoring of School Closures caused by COVID-19. Retrieved from https://en.unesco.org/covid19/educationresponse

Yulia, H. 2020. Online Learning to Prevent the Spread of Pandemic Corona Virus in Indonesia. ETERNAL (English Teaching Journal). 11(1) .

\section{Appendix}

Table 1 Distribution of respondents by Gender

Table 2 Codes for the Theme of Views on Distance Education

Table 3 Codes for the Theme of Presentation of Scientific Material from Distance Education

Table 4 Codes for the Theme of Teachers' Opinion on Distance Education

Table 5 Codes for the Theme of Teachers' Opinion on Assessing Students in the Electronic Environment 